\title{
ANALISIS MINAT BELAJAR SISWA KELAS III PADA MATERI BANGUN DATAR BERBANTUAN VBA
}

\author{
Dzarroh Qolba Musoffa ${ }^{1}$, Ani Nurhayati ${ }^{2}$, Siti Chotimah $^{3}$ \\ ${ }^{1,2,3}$ IKIP SILIWANGI, Jl. Terusan Sudirman, Cimahi Tengah, Kota Cimahi, Jawa Barat \\ dzarrohqol@gmail.com
}

\begin{abstract}
Abstrak
Interest in learning is one of the soft skills that are important for students to have. Because interest in learning will make it easier for students to achieve learning goals. While a lack of interest in learning can result in a lack of interest in a person in a particular field, it can even lead to rejection of the teacher. The focus of our research on the research sample is to determine the criteria for student interest in learning. This research is motivated by most elementary school (SD) students who do not like learning mathematics because mathematics is a subject that deals with numbers. This shows that students are less interested in learning mathematics. The method used in this research is descriptive qualitative with a sample of 11 people. The results of this study indicate the criteria for student interest in learning with the help of VBA are in the high category because the average percentage accumulation is $85.34 \%$. The VBA application is a learning medium that is arguably something new for elementary students in general. So that when the media is used in learning, it can attract students to pay attention and follow learning well.
\end{abstract}

Keywords : Interest in learning, two-dimentional figure, VBA

\begin{abstract}
Abstrak
Minat belajar merupakan salah satu soft skills yang penting untuk dimiliki siswa. Dikarenakan minat belajar akan memudahkan siswa mencapai tujuan belajar. Sedangkaan kurangnya minat belajar dapat mengakibatkan kurangnya rasa ketertarikan seseorang terhadap suatu bidang tertentu, bahkan dapat melahirkan sikap penolakan kepada guru. Fokus penelitian yang kami lakukan terhadap sample penelitian yaitu untuk mengetahui kriteria minat belajar siswa. Penelitian ini dilatarbelakangi oleh kebanyakan siswa Sekolah Dasar (SD) yang tidak menyukai pembelajaan nmatematika karena matematika itu adalah pelajaran yang bergelut dengan angka. Hal ini mnunjukan kurang minatnya belajar siswa terhadap pembelajaran matematika. Metode yang digunakan dalam penelitian ini adalah deskriptif kualitatif dengan sample 11 orang. Hasil dari penelitian ini menunjukkan kriteria minat belajar siswa dengan bantuan VBA sudah termasuk kategori tinggi karena terlihat akumulasi persentase rata-rata $85,34 \%$. Aplikasi VBA merupakan salah satu media pembelajaran yang bisa dibilang sesuatu yang baru bagi siswa SD pada umumnya. Sehingga ketika media tersebut digunakan dalam pembelajaran dapat menarik siswa untuk memperhatikan dan mengikuti pembelajaran dengan baik.
\end{abstract}

Kata Kunci : Minat belajar, Bangun Datar, VBA

\section{PENDAHULUAN}

Pendidikan merupakan suatu alat untuk meningkatkan taraf hidup suatu bangsa karena pendidikan adalah upaya meningkatkan kualitas sumber budaya manusia.pendidikan yang di tempuh salah satunya di sekolah, mulai dari jenjang Pendidikan Anak Usia Dini (PAUD) sampai dengan Perguruan Tinggi (PT). Salah satu mata pelajaran yang diajarkan di sekolah adalah matematika namun mata pelajaran matematika jarang di minati oleh siswa karena matematika di pandang oleh sebagian besar siswa merupakan mata pelajaran yang sulit..

Sehingga ketekutan siswa dalam belajar menjadi kurang (Nasutin dalam Strategi, Dan, Belajar, \& Firmansyah, 2015) bahwa ketekunan belajar ini bertalian dengan sikap dan minat terhadap pelajaran. Bila suatu pelajaran tidak menarik minat seseorang karena suatu hal, maka ia segera 
menyampingkannya jika menemukan kesulitan. Sebaliknya jika suatu tugas menarik karena memberikan hasil yang menggembirakan, ia cenderung meluangkan waktu yang lebih banyak untuk tugas itu.

(Maslow dalam Strategi et al., 2015) mengemukakan dorongan-dorongan untuk belajar yaitu adanya kebutuhan fisik, adanya kebutuhan rasa aman (bebas dalam kekuatan), adanya kebutuhan akan kecintaan dan penerimaan dalam hubungan dengan orang lain, adanya kebutuhan untuk mendapatkan kehormatan dari masyarakat, sesuai dengan sifat seseorang untuk mengemukakan atau mengetengahkan diri dengan kata lain minat belajar mengindikasikan adanya kecenderungan untuk berusaha aktif meraih manfaat yang diharapkan. Menurut (Slameto dalam trategi et al., 2015) mengatakan minat itu besar pengaruhnya terhadap belajar, oleh karena itu minat dapat ditumbuh kembangkan melalui belajar, sebab melalui belajar seseorang dapat menganalisis informasi-informasi tentang berbagai karakteristik objek kehidupan termasuk informasi tentang pendidikan, jabatan, serta tentang berbagai jenis pekerjaan. Lingkungan yang baik dan sehat dapat mendorong siswa untuk memiliki keinginan dan kegairahan belajar. Selain lingkungan, keinginan dan kegairahan belajar dipengaruhi oleh kondisi siswa itu sendiri pada saat belajar, jika kondisi yang dihadapi kurang mendukung biasanya siswa akan cenderung kurang berminat untuk belajar ataupun kurang konsentrasi dalam mengikuti setiap pelajaran yang diberikan (Neng Cucu Nurmaenah, Selvi Aginai, Yulianda Putri H, 2020).

Minat belajar adalah menunjukkan kondisi sibuk, tertarik, atau terlibat sepenuhnya dalam suatu kegiatan karena menyadari pentingnya kegiatan tersebut (Hendriana, Rohaeti, \& Sumarmo, 2017). Menurut Slameto (Flora Siagian, 2015) dalam buku belajar dan faktor-faktor yang mempengaruhinya menyatakan bahwa: "Minat adalah suatu rasa lebih suka dan rasa keterikatan pada suatu hal atau aktivitas, tanpa ada yang menyuruh". Sardiman (Lestari, 2015) menjelaskan minat merupakan suatu kondisi yang terjadi apabila seseorang melihat ciri-ciri atau arti sementara situasi yang dihubungkan dengan keinginan dan kebutuhannya sendiri.

Indikator yang dipakai pada penelitian ini yaitu : 1. Perasaan senang 2. Keterlibatan Siswa 3. Ketertarikan Siswa 4. Rajin dalam belajar dan rajin mengerjakan tugas matematika 5. Tekun dan disiplin dalam belajar dan memiliki jadwal belajar.

Kebanyakan siswa Sekolah Dasar (SD) tidak menyukai pembelajaan nmatematika karena matematika itu adalah pelajaran yang bergeqlut dengan angka. Hal ini mnunjukan kurang minatnya belajar siswa terhadap pembelajaran matematika. Salah satu penyebabnya adalah guru yang menyampaikan pelajaran matematika hanya dengan metode ceramah. Sehingga diperlukaannya sebuah inovasi dalam menyampaikan pembelajaran matematika salah satunya dengan menggunakan media pembelajaran yaitu Visual Basic Application (VBA). VBA merupakan salah satu media 
Analisis Minat Belajar Siswa Kelas III Pada Materi Bangun Datar Berbantuan VBA, Dzarroh Qolba Musoffa, Ani

pembelajaran yang bisa dibilang sesuatu yang baru bagi siswa SD pada umumnya. Sehingga ketika media tersebut digunakan dalam pembelajaran dapat menarik siswa untuk memperhatikan dan mengikuti pembelajaran dengan baik (Neng Cucu Nurmaenah, Selvi Aginai, Yulianda Putri H, 2020). Software ini bukan hanya menyediakan untuk keperluan kebutuhan laporan, poengolahan data namun juga untuk membuat alat peraga atau media interaktif.

Penelitian ini merupakan penelitian observasi awal. Tujuan penelitian ini untuk menelaah minat belajar siswa kelas tiga di SDIT ULUL AZMI pada materi bangun datar. Ketika minat belajar siswa sudah diketahui, selanjutnya guru perlu merancang pembelajaran yang memfasilitasi dan membiasakan siswa untuk melakukan kegiatan pembelajaran yang memanfaatkan aktifitas dilingkungan sehingga minat belajar siswa dapat meningkat. Rancangan pembelajaran itu berupa media pembelajaran yaitu aplikasi Visual Basic Acsess.

Dari uraian diatas dapat disimpulkan bahwa untuk menumbuhkan minat belajar dapat menggunakan media pembelajaran berupa aplikasi VBA.

\section{METODE}

Untuk penelitian ini metode yang digunakan adalah metode kualitatif. Metode ini disebut kualitatif karena lebih berdasarkan pada sifat fenomena logis yang mengutamakan penghayatan. Pada metode kualitatif peneliti harus memahami dan menafsirkan makna suatu peristiwa interaksi tingkah laku manusia dalam situasi tertentu menurut perspektif peneliti sendiri. Penelitian yang menggunakan penelitian kualitatif bertujuan untuk memahami objek yang diteliti secara mendalam. Penilitian ini bertujuan untuk meneliti minat belajar siswa dengan menggunakan aplikasi vba. Sampel dalam penelitian ini sebanyak 11 orang. Berikut ini bagan alur penelitian yang dilakukan

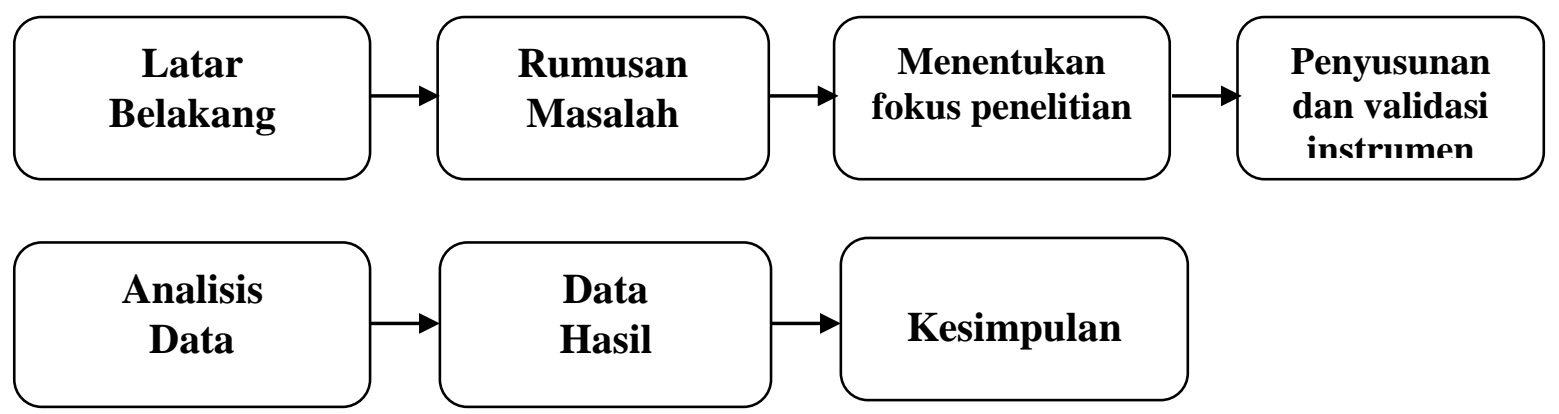

Gambar 1. Prosedur Pelaksanaan Penelitian

Teknik pengambilan data pada penelitian ini dilakukan dengan menggunakan angket minat belajar sejumlah 19 pertanyaan. Teknik analisis data yang digunakan dalam penelitian ini dilakukan dalam tiga tahap : 1. Reduksi data, dalam hal ini peneliti menganalisis data dengan menganlisis jawaban siswa 2. Penyajian data, hasil analisis yang dilakukan oleh peneliti disajikan dalam bentuk teks naratif, tabel hasil analisis serta kesimpulan 3. Tahap kesimpulan, merupakan pengambilan 
kesimpulan data yang telah diperoleh dari hasil reduksi dan penyajian data menurut (Tanu, Neng, Septiani, Indah, \& Fauziah, 2018) Moleong (2004 : 131) dalam pendekatan kualitatif yang dikumpulkan bukan berupa angka melainkan catatan lapangan, dokumen pribadi, catatan, memo, dan dokumen resmi lainnya. Sehingga yang menjadi tujuan dari penelitian ini adalah ingin menggambarkan realita empirik di balik fenomena secara mendalam rinci dan tuntas. Alat pengumpul data dalam metode kualitatif adalah si peneliti sendiri. Jadi peneliti merupakan keinstrumen dalam mengumpulkan data. Peneliti tersebut harus terjun kelapangan secara aktif.

Pada penelitian ini adalah berupa angket minat belajar. Prosedur dalam penelitian ini terdiri dalam tiga tahap yaitu 1. Tahap persiapan, 2. Tahap pelaksanaan, 3. Tahap akhir Indikator yang dipakai pada penelitian ini yaitu : 1. Perasaan senang 2. Keterlibatan Siswa 3. Ketertarikan Siswa 4. Rajin dalam belajar dan rajin mengerjakan tugas matematika 5. Tekun dan disiplin dalam belajar dan memiliki jadwal belajar.

Kriteria minat belajar yang digunakan oleh peneliti adalah bersumber dari Suharsimi Arikunto dalam Sriani, 2013: 28.

Tabel 1.

Kriteria Minat Belajar

\begin{tabular}{|c|c|}
\hline Presentase skor minat (\%) & Kriteria \\
\hline $76-100$ & Tinggi \\
\hline $56-76$ & Sedang \\
\hline $0-56$ & Rendah \\
\hline
\end{tabular}

\section{HASIL DAN PEMBAHASAN}

Penelitian ini dilaksanakan di kelas III di SDIT ULUL AZMI, sesuai dengan pertanyaan penelitian dilakukan pembahasan dan analisis jawaban untuk melihat minat belajar siswa pada materi bangun datar menggunakan Visual Basic Application (VBA). Cuplikan Visual Basic Application (VBA) yang digunakan adalah sebagai berikut :

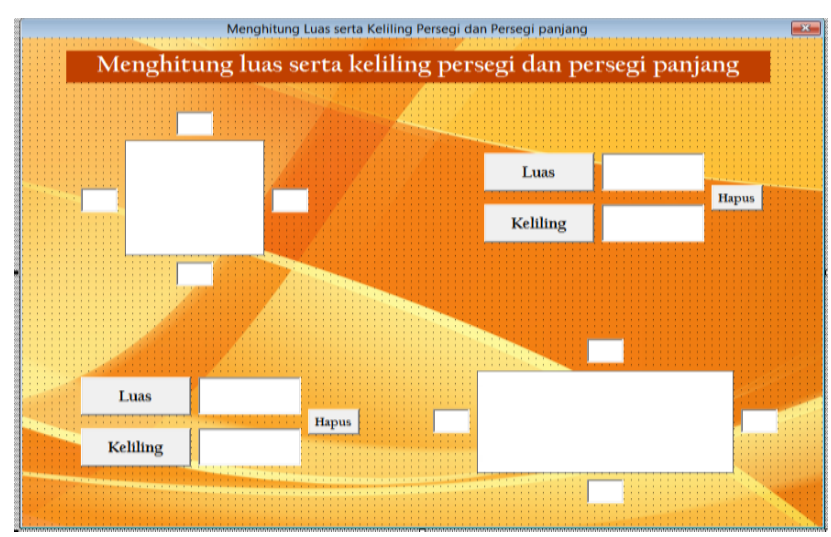

Gambar 2. Visual Basic Application (VBA) 
Analisis Minat Belajar Siswa Kelas III Pada Materi Bangun Datar Berbantuan VBA, Dzarroh Qolba Musoffa, Ani Nurhayati, Siti Chotimah

Mendeskripsikan minat belajar siswa tentang bangun datar pada tiap indikator. Sampel penelitian berjumlah 11 siswa. Data hasil penelitian ini berupa presentase tiap indikator yang berjumlah 5 indikator dengan 19 pernyataan.

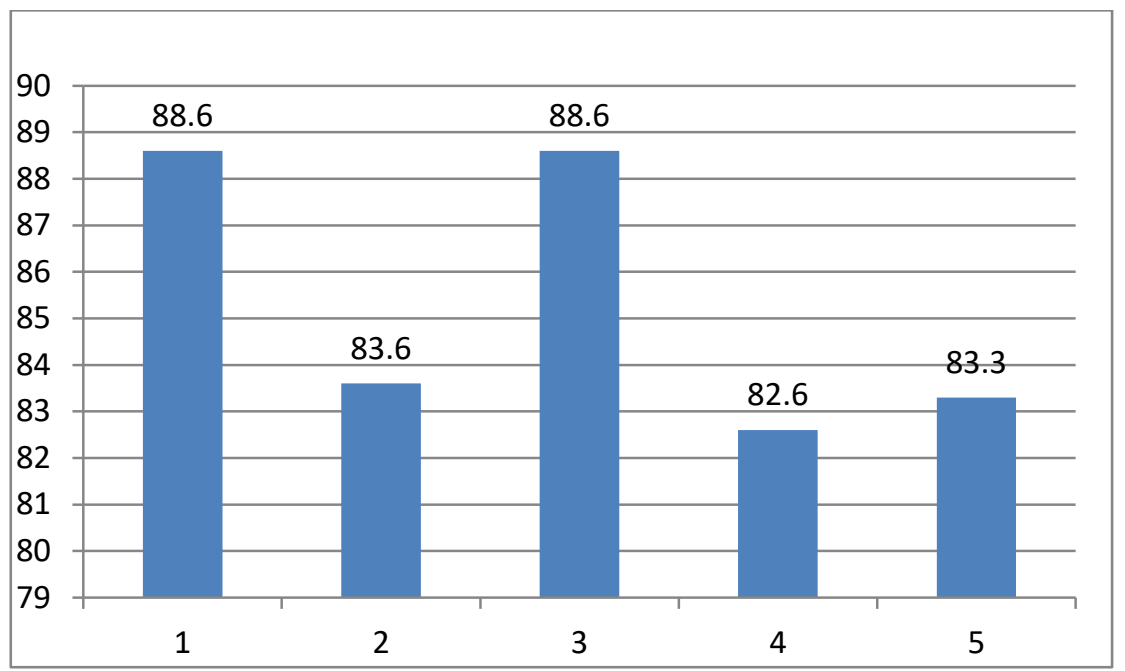

Gambar 3. Hasil Presentase Minat Belajar Siswa

Berdasarkan data yang tercantum pada tabel 1 menunjukkan bahwa indikator perasaan senang memiliki presentase $88,6 \%$. Berdasarkan presentase tersebut menunjukkan bahwa kriteria minat belajar siswa tinggi. Kemudian besar presentase untuk indikator Ketertarikan Siswa yaitu 83.6\%, presentase tersebut menunjukkan bahwa kriteria minat belajar siswa tinggi. Besar presentase untuk indikator Keterlibatan Siswa adalah 88,6\%, presentase itu menunjukkan bahwa kriteria minat belajar siswa tinggi. Untuk indikator Rajin dalam belajar dan rajin mengerjakan tugas matematika memiliki presentase $82,6 \%$. Indikator tekun dan disiplin dalam belajar dan memiliki jadwal belajar memiliki besar presentase $83,3 \%$. Berdasarkan persentasi tersebut menunjukkan bahwa kriteria minat belajar siswa tinggi. Hal ini sejalan dengan penelitian (Ernawati, Leni Nurhayati, 2020) bahwa pembelajaran matematika berbantuan media ICT VBA dapat meningkatkan minat belajar siswa. Sehingga penggunaan media ICT VBA dapat menjadi salah satu alternatif untuk menjadikan pembelajaran lebih menarik dan menyenangkan. (Ernawati, Leni Nurhayati, 2020).

\section{KESIMPULAN}

Berdasarkan hasil dan pembahasan dari penelitian yang telah dilakukan, dapat disimpulkan bahwa indikator perasaan senang memiliki presentase $88,6 \%$. Untuk indikator ketertarikan siswa yaitu 83.6\%, presentase tersebut menunjukkan bahwa kriteria minat belajar siswa tinggi. Presentase indikator keterlibatan siswa adalah $88,6 \%$. Indikator rajin dalam belajar dan rajin mengerjakan tugas matematika memiliki presentase $82,6 \%$. Indikator tekun dan disiplin dalam belajar dan memiliki 
jadwal belajar memiliki besar presentase $83,3 \%$. Berdasarkan persentasi tersebut menunjukkan bahwa kriteria minat belajar siswa terhadap materi bangun datar dengan berbantuan Visual Basic Application adalah tinggi. Terutama pada indikator perasaan senang dan indikator keterlibatan siswa. Sehingga penggunaan Visual Basic Application dapat menjadi salah satu alternatif untuk menjadikan pembeajaran menarik.

\section{DAFTAR PUSTAKA}

Ernawati, Leni Nurhayati, S. C. (2020). Analisis Pengaruh Penggunaan Visual Basic Application Terhadap Minat Belajar Matematika Siswa SD pada Materi Bilangan Prima Analysis of interest in Learning Elementary School on Prime Numbers Assisted by Visual Basic Application. 10(April).

Flora Siagian, R. E. (2015). Pengaruh Minat dan Kebiasaan Belajar Siswa terhadap Prestasi Belajar Matematika. Formatif: Jurnal Ilmiah Pendidikan MIPA, 2(2), 122-131. https://doi.org/10.30998/formatif.v2i2.93

Hendriana, H., Rohaeti, E. E., \& Sumarmo, U. (2017). Hard skills dan Soft skills Matematik Siswa (F. Atif, Nurul, ed.). Cimahi: PT Refika Aditama.

Lestari, I. (2015). Pengaruh Waktu Belajar dan Minat Belajar terhadap Hasil Belajar Matematika. Formatif: Jurnal Ilmiah Pendidikan MIPA, 3(2), 115-125. https://doi.org/10.30998/formatif.v3i2.118

Neng Cucu Nurmaenah, Selvi Aginai, Yulianda Putri H, S. C. (2020). KPK DAN FPB MENGGUNAKAN PENDEKATAN SAINTIFIK BERBANTUAN APLIKASI VISUAL BASIC EXCEL ( VBE ). Journal On Education, 02(04), 275-282.

Strategi, P., Dan, P., Belajar, M., \& Firmansyah, D. (2015). Issn 2338-2996. 3, 34-44.

Tanu, T., Neng, W., Septiani, S., Indah, D., \& Fauziah, R. (2018). Analisis Kemampuan Pemahaman Matematis Siswa Kelas IX Pada Materi Bangun Ruang. 6(1), 19-28. 